\title{
Morphometric Studies on Rat Seminiferous Tubules
}

\author{
TUNG-YANG WING AND A. KENT CHRISTENSEN \\ Department of Anatomy and Cell Biology, The University of Michigan \\ Medical School, Ann Arbor, Michigan 48109
}

\begin{abstract}
The goal of this morphometric study was to obtain quantitative information on the seminiferous tubules of Sprague-Dawley rats, including changes seen at various stages of the cycle of the seminiferous epithelium. Tissue from perfusion-fixed testes was embedded in Epon-Araldite; and sections were subjected to morphometric measurements at the light microscopic level, using point counting for volume densities and the Floderus equation for numerical densities.

Changes occur in the diameter of the seminiferous tubule, as well as in the volume of the seminiferous epithelium and tubule lumen, from stage to stage during the cycle. A significant constriction of the seminiferous tubule accompanies spermiation. The volume of the seminiferous epithelium per unit length of the tubule begins to increase after stage XIV, and peaks at stage V of the next cycle. The tubule lumen increases dramatically from stages V to VII, at the expense of the epithelium.

The number of Sertoli cells is constant per unit length of the seminiferous tubule at all stages of the cycle. This is also true for primary spermatocytes of various developmental phases and for round spermatids from step 1 through step 10 of spermiogenesis. The average number of younger (preleptotene, leptotene, zytgotene) primary spermatocytes per Sertoli cell is $2.34 \pm 0.082$ (SEM), the number of older (pachytene, diplotene) primary spermatocytes per Sertoli cell is $2.37 \pm$ 0.064 , and the ratio of step 1-10 spermatids to Sertoli cells is $7.89 \pm 0.27$. By studying tangential views of serially sectioned seminiferous tubules at stage $\mathrm{V}$, it is shown that the number of step-17 spermatids associated with each Sertoli cell averages $8.35-0.128$, although the counts ranged from 6 to 11 . The only appreciable occurrence of cell death after the last spermatogonial mitosis appears to be a $15 \%$ loss during the first meiotic division. From our morphometric results, corrected for volume changes during preparation for microscopy, there are 15.7 million ( \pm 0.99 million) Sertoli cells per gram of fresh rat testis. The length of seminiferous tubule per gram of testis is estimated to be $12.4 \pm 0.56$ meters, and the tubule surface area per gram testis is $119.7 \pm 2.57 \mathrm{~cm}^{2}$. The daily production of mature spermatids is 9.61 million ( \pm 0.615 million) per gram of testis.
\end{abstract}

Accurate morphometric information can provide answers to important questions about the spermatogenic process, and is also valuable for correlations with physiological and biochemical findings in order to develop a more complete understanding of spermatogenesis. The literature on the rat testis contains a considerable number of quantitative studies on cell numbers in the seminiferous tubule, and on changes in the tubule at various stages of the cycle of the seminiferous epithelium (RoosenRunge and Giesel, 1950; Clermont and Leblond, 1953; Roosen-Runge, 1955a,b; Clermont and Morgentaler, 1955; Clermont and Perey,
1957; Clermont, 1962; Bustos-Obregon, 1970; Clermont and Hermo, 1975; Russell and Clermont, 1977). Improvements in stereological principles and methods over the last decade (Weibel and Bolender, 1973; Bolender, 1978; Elias and Hyde, 1980) have made it seem

Presented in partial fulfillment of requirements for the Ph.D. degree in the Department of Anatomy and Cell Biology at the University of Michigan Medical School.

Dr. Wing's current address is: Division of Reproductive Biology, Department of Population Dynamics, School of Hygiene and Public Health, The Johms Hopkins University, Baltimore, MD 21205.

Reprint requests should be sent to Dr. Christensen.

Received December 31, 1981. Accepted May 7, 1982. 
worthwhile to reassess some of the previous quantitative conclusions, as well as to look into some additional morphometric aspects that may have functional correlations.

In this study we have sought detailed quantitative information on the rat seminiferous tubule. We have counted the numbers of Sertoli cells and germ cells (from preleptotene primary spermatocytes to step-10 spermatids) that are present in unit volume and in unit length of the seminiferous tubule, as well as in unit volume of the testis. We have related the number of germ cells of various types to the number of Sertoli cells to give some insight into the supportive load carried by Sertoli cells. By comparing the number of germ cells of particular developmental phases (beyond spermatogonia), we have shown where cell death occurs during spermatogenesis. We have also followed variations in size of the seminiferous tubule and its component epithelium and lumen throughout the cycle. We have derived the total length of the seminiferous tubule in a rat testis and have estimated the average number of mature spermatids produced per day by the rat testis.

In an effort to obtain quantitative information that is as accurate and useful as possible, we have included various procedures in our study that have not been common in previous quantitative studies on seminiferous tubules. For example, we have used perfusion fixation of the testis with glutaraldehyde fixative and have embedded it in Epon-Araldite to provide favorable structural preservation. We have sought absolute rather than relative values for cell numbers, utilizing the Floderus equation. The resulting estimates of cell number per gram of tissue may be useful in correlating these results with biochemical studies. Our final data have been corrected for the considerable volume changes that take place during preparation for microscopy; thus the data provide values for cell numbers per gram of fresh tissue. The large body of information generated by our counts has been analyzed and formulated by morphometric methods using the central computer system of the University of Michigan to improve the accuracy and flexibility of data handling. Extensive statistical programs available with this computer system have been utilized to test the validity and significance of the results. By these means we have attempted to obtain quantitative data that may serve as a baseline for correlation with studies of various kinds in the future.

\section{MATERIALS AND METHODS}

Four male Sprague-Dawley rats of $64,54,77$, and 77 days of age, and weighing respectively $256 \mathrm{gm}, 284 \mathrm{gm}, 293 \mathrm{gm}$ and $318 \mathrm{gm}$, were used in this study. The animals were acclimated on a 14-hour light and 10-hour dark schedule and fed with normal rat chow and water ad libitum. Animals were sacrificed between 10:00 a.m. and noon. Under ether anesthesia, both testes of an animal were perfusion-fixed (Christensen, $1965)$ with $5 \%$ glutaraldehyde in $0.1 \mathrm{M} \mathrm{s}$-collidine buffer of $\mathrm{pH} 7.4$, containing $0.005 \% \mathrm{CaCl}_{2}$, at room temperature for 45 minutes. The volume of the perfused testis was measured by water displacement. Each testis was sliced into 10 slices perpendicular to the long axis of the organ. The better fixed tesis of the two from an animal was used for the study. Slices were diced into tissue blocks about $2 \mathrm{~mm}$ on a side. Thirty tissue blocks, selected randomly, were left in $0.1 \mathrm{M}$ s-collidine buffer ( $\mathrm{pH}$ 7.4) overnight, dehydrated with graded ethanols $(70 \%, 80 \%, 95 \%$, and $100 \%)$, and embedded in Epon-Araldite. The tissue blocks were oriented to have most of the seminiferous tubules cut in cross section. Sections were cut with glass knives on a Porter-Blum MT-2 ultramicrotome, with the thickness reading set at $4 \mu \mathrm{m}$ and the speed of the block movement kept constant throughout the sectioning in the study. Three to four sections were placed on a drop of water on a glass slide, dried on a hot plate (about $70^{\circ} \mathrm{C}$ ), and stained with $1 \%$ borate-toluidine blue for 3 minutes.

The basic morphometric methods used in this study are described in reviews by Weibel and Bolender (1973) and Elias and Hyde (1980), which can be consulted for background and formula derivations.

One section from each of the 30 tissue blocks sampled from each animal was used for analysis. The sections were analyzed under a binocular Zeiss microscope fitted with a 400-point Bausch and Lomb reticle in one of its $8 \times$ eyepieces. In the morphometric measurements, the orientation of the eyepiece, and therefore the reticle, was random.

The volume densities (volume per unit volume) of the interstitial tissue and the seminiferous tubule in the testis were measured with a Zeiss $16 \times / 0.40$ N.A. neofluar objective. On each section, the volume density was derived from the number of points over the respective structure divided by the total points over the testicular tissue. The mean of the 30 measure- 
ments for each animal was taken as the volume density of the structure in the animal.

Every complete seminiferous tubule profile in a section (usually $5-10$ ) was included in the following analyses. The stage of the cycle of the seminiferous epithelium seen in the profile was identified according to Leblond and Clermont (1952a,b). Owing to the lack of reliable criteria to differentiate stages I-IV in the present material, they were pooled as a single group in analyses. Diameters of the tubule were measured across the minor axis of their profiles. The volume and surface area of the seminiferous tubule were calculated from the diameter, as is described below. The relative volume of the lumen in the tubule (luminal ratio) was measured by point-counting five times for each tubule profile, the orientation of the reticle and the position of the seminiferous tubule profile being changed for each measurement; the multiple measurements permitted a relative standard error of less than $5 \%$ to be obtained for the least numerous stages of the cycle. The counts of seminiferous-tubule profile areas were rather consistent, as indicated by a coefficient of variation of $7 \%$ or less for each seminiferous tubule used in this study, which is adequate for most morphometric studies.

The volume of the seminiferous epithelium or tubular lumen per unit length of the tubule for each stage of the cycle was derived from luminal ratios and diameters. These values, together with the diameter changes during the cycle, yield insight into cyclic events of the seminiferous epithelium.

From 150 to 200 seminiferous-tubule profiles were sampled and analyzed for each of the four animals used in this study. Information about the animal, stage, and original measurements of individual seminiferous-tubule profiles was stored in computer files in the central computer facility of the University of Michigan and processed with a statistical package, MIDAS (Michigan Interactive Data Analysis System, Fox and Guire, 1976). Calculations or transformations were carried out in MIDAS, and stage differences in seminiferous tubule diameter, luminal ratio and epithelial or luminal volume per unit length of the seminiferous tubule were compared by using one-way ANOVA and Scheffe's test in MIDAS (Snedecor and Cochran, 1980).

Relationships among volume, length, and surface area of the seminiferous tubule per testis or per $\mathrm{cm}^{3}$ of testis were derived from a tube model in which the seminiferous tubule was assumed to be a round tube with a radius ( $\mathrm{r}$ ), a length ( $\mathrm{L}$ ) through the tubular center, and a basement-membrane surface area (S). According to the standard equations for such a cylinder, the volume $(V)$ equals $\pi r^{2} L$, while $S=2 \pi r L$. Since we can measure the volume and can derive the radius from the measured average diameter of the seminiferous tubule, it is possible to calculate the length and the surface area. The seminiferous tubule of a rat actually shows numerous hairpin turns (Clermont and Huckins, 1961), but geometric considerations indicate that these turns would not affect our analyses. The curved portion of a hairpin turn can be represented geometrically as a segment of a torus with a radius of curvature $(R)$, and with $\mathrm{r}, \mathrm{S}$, and $\mathrm{L}$ defined as above. The volume of a torus is $V=2 \pi^{2} r^{2} R$, the surface area is $S=$ $4 \pi^{2} \mathrm{rR}$, while the length is $\mathrm{L}=2 \pi \mathrm{R}$. From the last equation it is clear that $\mathrm{R}=\mathrm{L} /(2 \pi)$, and so $\mathrm{V}=\pi \mathrm{r}^{2} \mathrm{~L}$ and $\mathrm{S}=2 \pi \mathrm{rL}$, which is the same as for a cylinder. It can be shown that the same equations are valid for any segment of a torus. The relationship between volume, surface area, and length used in the present study for seminiferous tubules are therefore appropriated whether the tubule is straight or bent.

The number of germ cells and Sertoli cells per unit volume of the seminiferous tubule (numerical density) was derived with the Floderus (1944) equation

$$
\mathrm{N}_{\mathrm{V}}=\mathrm{N}_{\mathrm{A}} /(\mathrm{T}+\mathrm{D}-2 \mathrm{~h})
$$

where $N_{V}$ is the numerical density, $N_{A}$ is the number of nuclei or nucleoli counted per unit area of the seminiferous tubule profile, $T$ is the section thickness, $\mathrm{D}$ is the diameter of the object, and $h$ is the height of the smallest visible cap sections (see below). Methods used to secure a reliable estimation of each parameter need further explanation.

The counts that yield $\mathrm{N}_{\mathrm{A}}$ were carried out under oil immersion with a Zeiss $100 \times / 1.30$ N.A. planapochromatic objective. The nuclear profile of each germ cell in the seminiferous tubule, from preleptotene primary spermatocytes to step-10 spermatids, was counted in the respective seminiferous tubules. The number of Sertoli-cell nucleoli was also recorded. The seminiferous-tubule profile area was determined by point counting.

Throughout this study, no more than one distinguishable nucleolus was ever observed in a Sertoli-cell nuclear profile. Extensive analysis of serial sections showed that each Sertoli cell 
contains one and only one prominent nucleolus, which was therefore used to represent the Sertoli cell number. These findings are in agreement with those of Bustos-Obregon (1970).

The corrected thickness of the sections (T) used in the equation was derived from the measurement of cross sections of 28 reembedded sections. The thickness was found to be $5.00 \pm 0.05 \mu \mathrm{m}$ (SEM). Measurements of the diameter (D) of Sertoli-cell nucleoli and germ-cell nuclei were carried out by the method of Christensen and Peacock (1980). Measurements of long and short axes of these structures showed that they were essentially spherical.

The height of the smallest visible cap sections $(\mathrm{h})$ of a nucleus or nucleolus was assumed to be $1 / 10$ of the diameter of the structure (Mori and Christensen, 1980). An exception was made for the very large primary spermatocytes at pachytene and diplotene phases, for which the value of $\mathrm{h}$ was taken to be $0.5 \mu \mathrm{m}$.

In morphometric studies it is customary to express volumes in terms of " $\mathrm{cm}^{3}$ ". However, for biochemical applications of morphometric data, it is generally more useful to have the volume information in terms of "grams." The two values "cm" and "grams" are essentially interchangeable, since the specific gravity of fresh testis tissue from rats is very near unity, 1.040 \pm 0.004 SEM (Mori and Christensen, 1980). We have therefore described the numerical densities presented in Table 3 in terms of "number per gram of testis tissue," although in a strict sense they are actually "number per $\mathrm{cm}^{3}$ of testis tissue."

The number of cells of a given type per unit length of the seminiferous tubule $\left(\mathrm{N}_{L}\right)$ was derived by multiplying the numerical density of the cell in the seminiferous tubule $\left(N_{V}\right)$ by the average cross-sectional area of the seminiferous tubule of this stage, of $N_{L}=N_{V} \pi r^{2}$. This relationship is derived as follows: If $\mathbf{r}$ is the average radius of the tubule, $n$ is the cell number in the seminiferous-tubule segment, and $\mathrm{V}$ is the volume and $\mathrm{L}$ is the length of the segment, then by definition $\mathrm{N}_{\mathrm{V}}=\mathrm{n} / \mathrm{V}$ and $\mathrm{N}_{\mathrm{L}}$ $=\mathrm{n} / \mathrm{L}$, yielding $\mathrm{VN}_{\mathrm{V}}=\mathrm{LN}_{\mathrm{L}}$ or $\mathrm{N}_{\mathrm{L}}=\mathrm{N}_{\mathrm{V}}(\mathrm{V} / \mathrm{L})$. However, for a cylinder, $\mathrm{V}=\pi \mathrm{r}^{2} \mathrm{~L}$, or $\mathrm{V} / \mathrm{L}=\pi \mathrm{r}^{2}$, which gives $\mathrm{N}_{\mathrm{L}}=\mathrm{N}_{\mathrm{V}} \pi \mathrm{r}^{2}$.

Calculations or transformations of numerical densities and cell numbers per unit length of the seminiferous tubule were performed in MIDAS. Stage differences in these values were compared with one-way ANOVA and Scheffe's test in MIDAS at the 95\% level, on the basis of individual seminiferous tubule profiles (Snedecor and Cochran, 1980).
The number of germ cells per Sertoli cell was obtained by comparing average cell numbers in a unit length of the seminiferous tubule. The rate of cell death during spermatogenesis was derived by similar numerical comparisons.

The number of step-17 spermatids in a cluster within individual Sertoli-cell trunks was determined by studying serial sections of longitudinally oriented tubules in each of the four animals used in this study. These sections allowed the spermatid clusters to be viewed in cross section in successive serial sections, and the number of spermatids constituting the cluster to be counted. Tubules at stage V of the cycle were analyzed in $2-\mu \mathrm{m}$ serial sections photographed at $400 \times$ magnification, and 100 clusters were analyzed. The clusters were used only if the spermatids could be traced throughout their length in the seminiferous epithelium.

It was important to determine the change in volume that the testis tissue undergoes during preparation for microscopy in order to relate the data obtained on sections to values for the fresh testis. The alterations during tissue preparation might be expected to occur during perfusion-fixation, dehydration and embedding, and during sectioning.

Changes during perfusion-fixation were measured in four testes from two SpragueDawley rats. Testes were taken from the anesthetized animals, the surrounding connective tissue was trimmed away, and their volumes were measured by fluid displacement before and after the perfusion-fixation. The perfusionfixed testis was $13.4 \% \pm 0.16 \%$ (SEM) larger than the fresh testis, corresponding to an increase in linear dimension of $2.38 \%(1.134=$ $\left.1.0238^{3}\right)$

The change during dehydration and embedding was measured in 10 tissue blocks from each of the four animals used in the morphometric measurements. The length of an axis in a tissue block was measured with a Zeiss 2.5 plan objective. The tissue blocks were then processed through the usual procedure of dehydration and embedding. After the polymerization of the resin, the axial length was measured again. The index of shrinkage in one dimension was derived as the ratio of the length of the axis in resin to the length of the same axis before dehydration and embedding. The value obtained was $0.7713 \pm 0.0059$ (SEM), or a reduction of $22.87 \%$. All axes showed similar indices. This change in linear dimension during dehydration and embedding would cause the volume of the embedded tissue to be reduced to $45.88 \%\left(=0.7713^{3}\right)$ of the value the tissue had after perfusion-fixation. 
The effect of compression during sectioning was verified by comparing the vertical height of every trimmed tissue block with the corresponding length of sections cut from the block. The change amounted to a factor of only 1.0138 \pm 0.0032 (SEM, $\mathbf{n}=120$ ). Since this factor is very small, and would be present only in one dimension of the section, it has been ignored in the data corrections.

The combined effect of the changes described above can be evaluated by multiplying the change factors for the successive stages of specimen preparation. Thus the overall change in linear dimension from the fresh testis to the tissue in the final sections is a factor of 0.79 $(=1.0238 \times 0.7713)$, which reflects a reduction of $21 \%$ in linear dimension during processing for microscopy. Since volume is the cube of linear dimension, the change in volume is more striking. During the complete procedure in the present study, the testis tissue was reduced to a volume $52.21 \%(=1.138 \times 0.4588)$ that of the fresh tissue.

These correction factors have been applied to all the data in this paper in order to provide values expressed in terms of the intact testis. For example, for numerical densities, the number of cells counted per unit volume of tissue was multiplied by 0.52 to provide the number of cells per $\mathrm{cm}^{3}$ of fresh tissue. The length of seminiferous tubule as calculated from measurements was multiplied by $0.647(0.7952$ to the $2 / 3$ power) in order to obtain the length of seminiferous tubule per $\mathrm{cm}^{3}$ of fresh testis. The surface area of basement membrane of the seminiferous tubule, derived from the sections, was multiplied by 0.804 (the cube root of 0.7952 ) to give the total surface area per $\mathrm{cm}^{3}$ of intact testis.

\section{RESULTS}

The quality of preservation in the perfusionfixed, plastic-embedded material used in this study (Fig. 1,2) makes it favorable for morphometric analysis. Tissue relationships are well maintained, and stages of the cycle of the seminiferous epithelium (Leblond and Clermont, 1952a,b) can be identified clearly, except for stages I to IV which were analyzed as a single group for the purposes of this study.

Changes in the diameter of the seminiferous tubule at various stages of the cycle are shown in Figure 3. The diameter increases significantly $(p<0.05)$ from stages I-IV to stages VII and VIII, and then undergoes a significant de crease $(p<0.05)$ from stages VIII to IX. Thereafter, the diameter remains significantly smaller than that of stages VII and VIII until stage $\mathrm{V}$ of the next cycle. No differences in diameters are found associated with the meiotic divisions.

There is a significant increase in volume of the lumen per centimeter of seminiferous tubule (Fig. 3) between stages V and VIII, leading up to spermiation; this is followed by a significant decrease in the luminal volume which occurs simultaneously with the decrease in tubular diameter. The prominent decrease in the diameter of the seminiferous tubule is caused by the depletion of the luminal contents instead of by the loss of the germinal epithelium, since the latter remains relatively constant over the portion of the cycle in which the tubule diameter is decreasing (Fig. 3). The volume of the germinal epithelium per unit length of seminiferous tubule increases significantly ( $p<0.05$ ) from stage XIV to reach a maximum at stage $V$ of the next cycle; thereafter there are significant decreases from stages V to VI and from stages VI to VII.

Figure 4 shows cell numbers per unit length of the seminiferous tubule at various stages of the cycle. No significant difference in cell number for a given cell category can be found between any two stages of the cycle. The distribution of Sertoli cells or a particular category of germ cells along the seminiferous-tubule length is thus concluded to be constant throughout the cycle in spite of the size fluctuations in the tubule. Figure 4 does not include secondary spermatocytes. The number of secondary spermatocytes per $\mathrm{cm}$ length of the seminiferous tubule in which they occur is $6.35 \times 10^{4} \pm 0.52$ $\times 10^{4}(\mathrm{SEM}, \mathrm{n}=4)$.

Table 1 shows the numerical ratios of various germ-cell categories to one another, on the basis of their numbers per unit length of seminiferous tubule. The numerical ratio of the younger (preleptotene, leptotene, and zygotene phases) and the older (pachytene and diplotene) generations of primary spermatocytes indicates that there is no cell loss as the younger generation develops into the more mature primary spermatocytes.

The numerical ratio of secondary spermatocytes to the older generation of primary spermatocytes is 1.70 , which is less than the value of 2.0 that would be expected if no cell loss occurred during the first meiotic division. The cell death rate during the first meiotic division is therefore about $15 \%(14.8 \% \pm 3.30 \%$, SEM). Table 1 also shows a numerical ratio of 1.98 between spermatids (steps 1-10) and secondary spermatocytes, indicating an absence of cell death during the second meiotic division. 


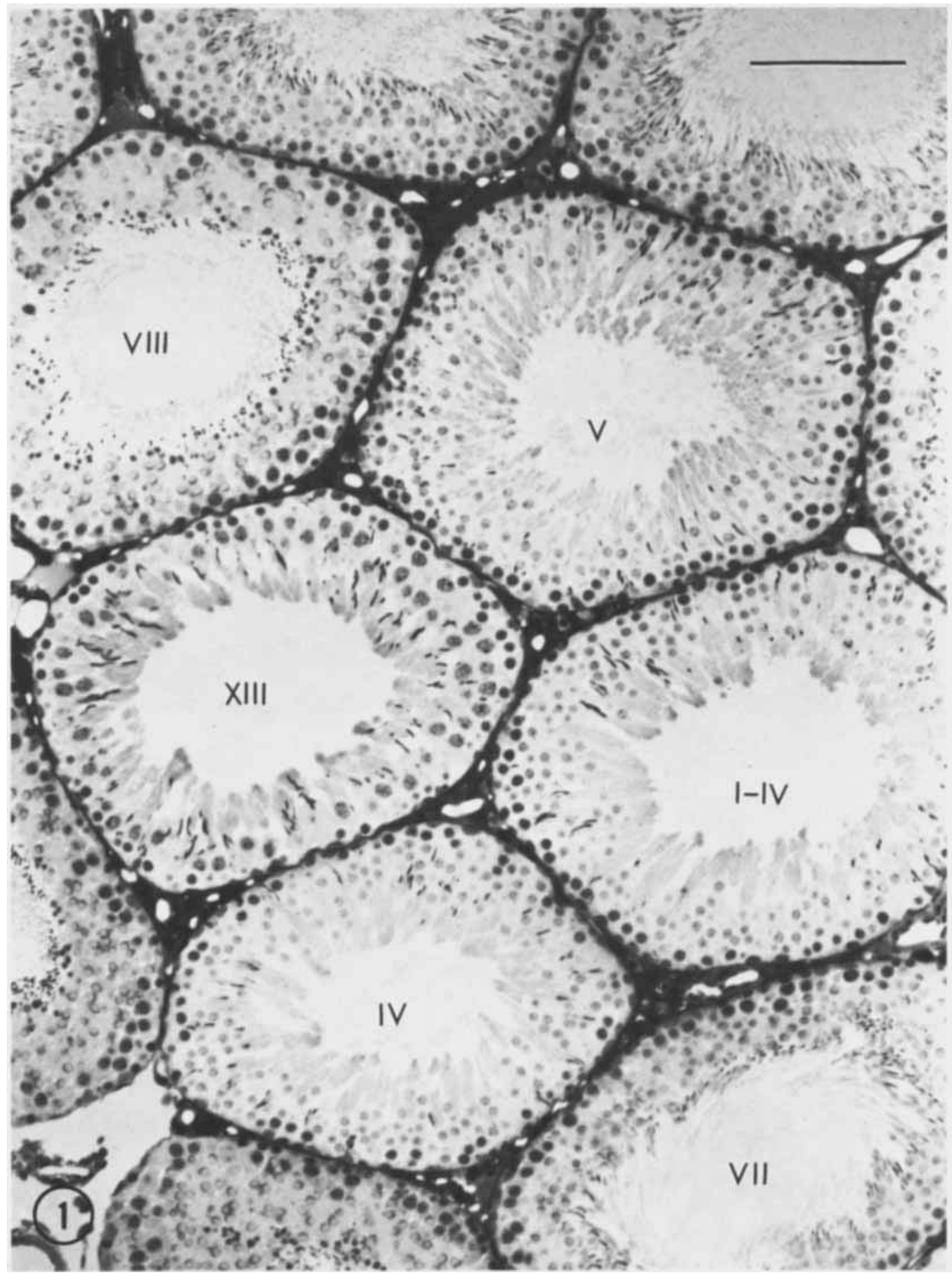

Fig. 1. Light micrograph of rat testis fixed by perfusion and embedded in Epon-Araldite. The seminiferous tubules and interstitial tissue are well-maintained, providing favor able material for morphometric analysis. Stages of the cycle of the germinal epithelium are labeled. $\times 215$. Bar $=100 \mu \mathrm{m}$. 

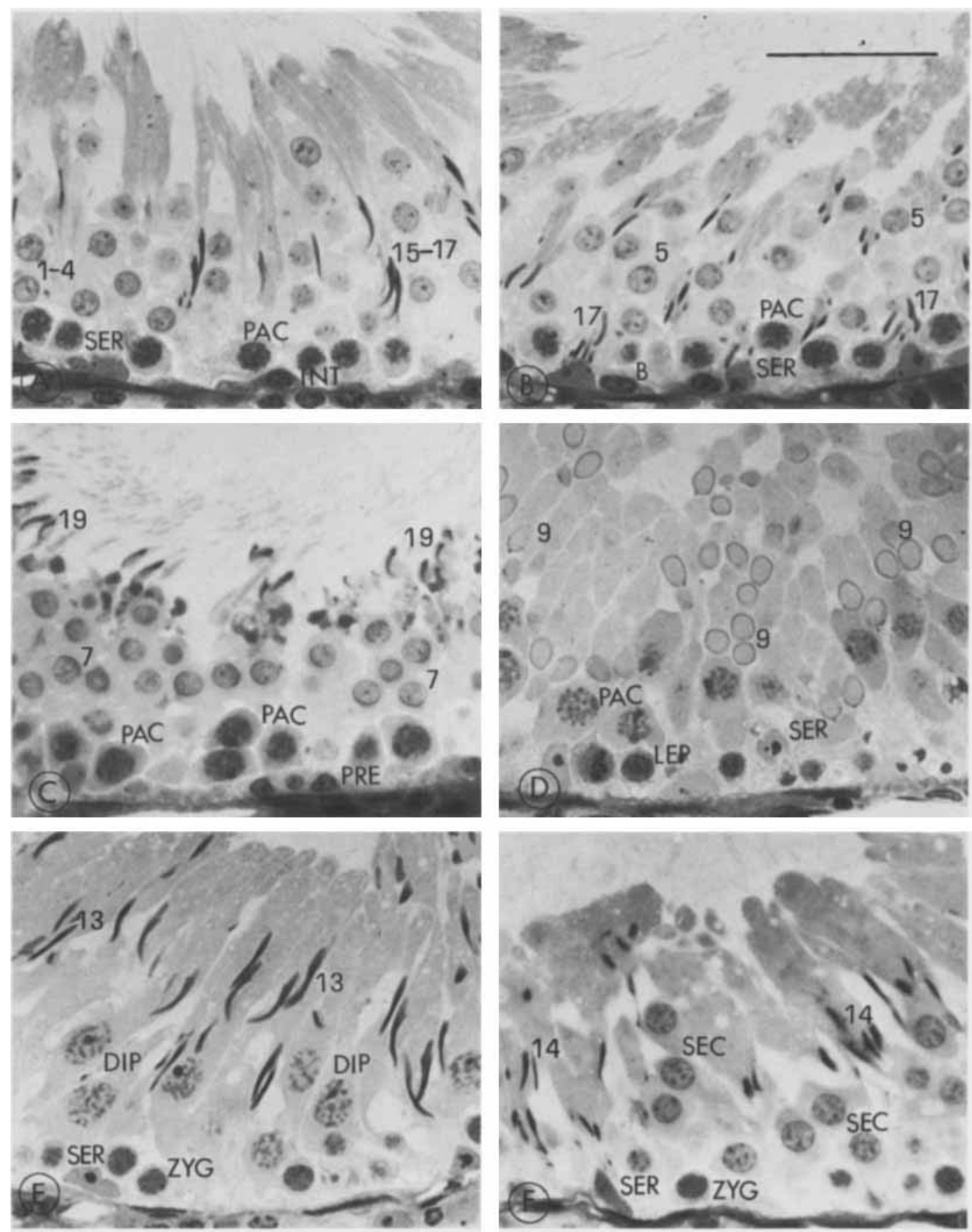

Fig. 2. Representative stages of the cycle of the seminiferous epithelium viewed at higher magnification, showing the level of preservation. Shown are A) stages I-IV, which are pooled in the present study, B) stage V, C) stage VII, D) stage IX, E) stage XIII, and F) stage XIV. Labeled in the figures are Sertoli cells (SER); type B (B) and intermediate

(INT) spermatogonia; primary spermatocytes in preleptotene (PRE), leptotene (LEP), zygotene ( $\mathrm{YYG}$ ), pachytene (PAC), and diplotene (DIP) phases; secondary spermatocytes (SEC); and spermatids at various steps (arabic numer als) of spermiogenesis. $\times 575 . \mathrm{Bar}=50 \mu \mathrm{m}$. 


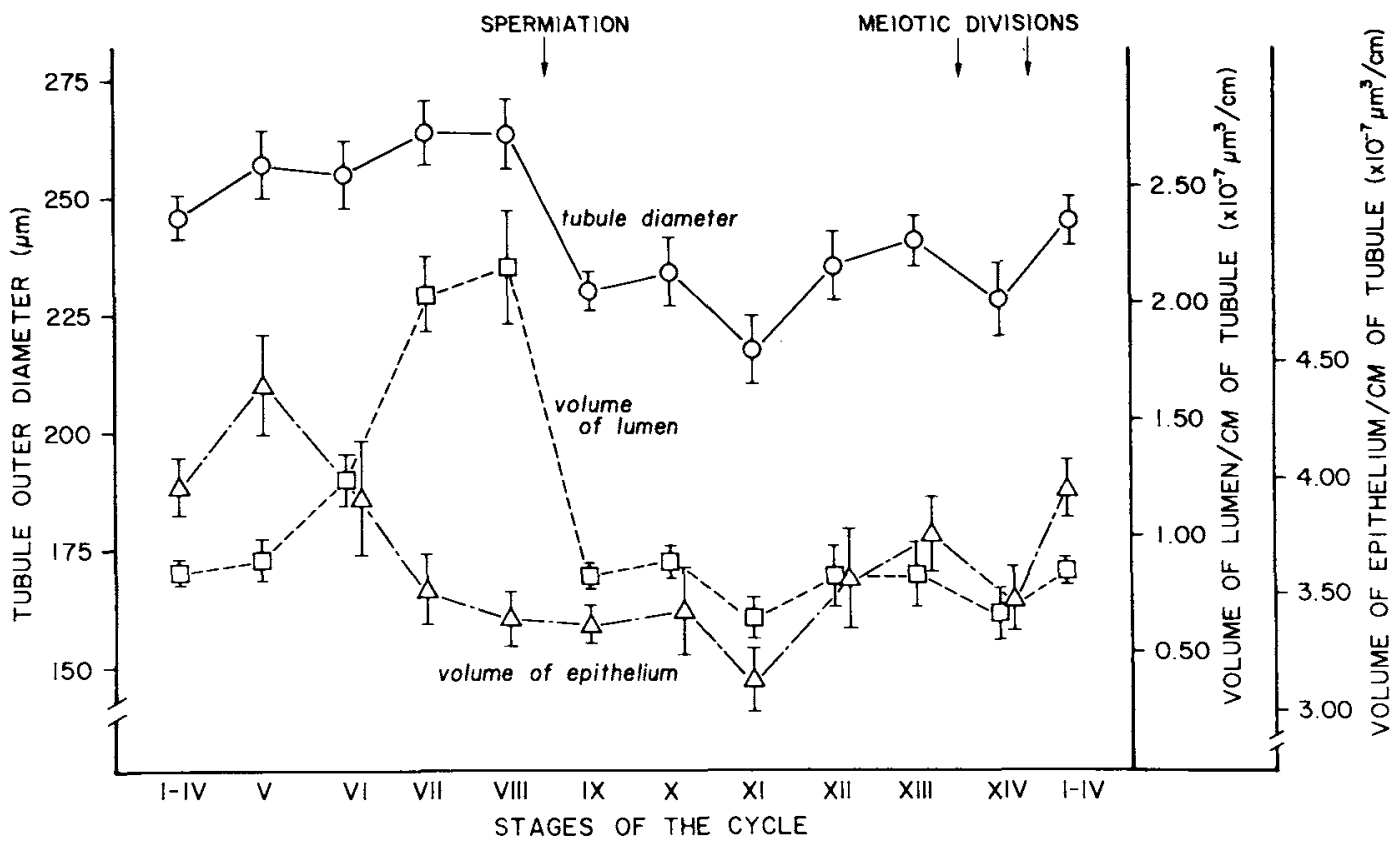

Fig. 3. Diameter of the seminiferous tubule, and volume of the epithelium and the lumen per unit length of seminifer- ous tubule at various stages of the cycle. Each value represents the mean of four animals ( \pm SEM).
TABLE 1. Numerical ratios of various germ cell generations *

\begin{tabular}{|c|c|c|}
\hline Ratio of & To & $\begin{array}{c}\text { Ratios } \\
( \pm \text { SEM })\end{array}$ \\
\hline $\begin{array}{l}\text { Pachytene } \\
\text { and diplotene } \\
\text { primary } \\
\text { spermatocytes }\end{array}$ & $\begin{array}{l}\text { Preleptotene, } \\
\text { leptotene, and } \\
\text { zygotene primary } \\
\text { spermatocytes }\end{array}$ & $1.01 \pm 0.009$ \\
\hline $\begin{array}{l}\text { Secondary } \\
\text { spermatocytes }\end{array}$ & $\begin{array}{l}\text { Pachytene and } \\
\text { diplotene primary } \\
\text { spermatocytes }\end{array}$ & $1.70 \pm 0.066$ \\
\hline $\begin{array}{l}\text { Young generation } \\
\text { spermatids } \\
\text { (steps 1-10) }\end{array}$ & $\begin{array}{l}\text { Secondary } \\
\text { spermatocytes }\end{array}$ & $1.98 \pm 0.158$ \\
\hline $\begin{array}{l}\text { Young generation } \\
\text { spermatids } \\
\text { (steps 1-10) }\end{array}$ & $\begin{array}{l}\text { Pachytene and } \\
\text { diplotene primary } \\
\text { spermatocytes }\end{array}$ & $3.34 \pm 0.157$ \\
\hline
\end{tabular}

*Ratios derived from cell numbers per unit length $(\mathrm{cm})$ of the seminiferous tubule.

In order to verify further the overall cell death rate over the two meiotic divisions, the numerical ratios of spermatids to the older-generation primary spermatocytes is seen in Table 1 to be 3.34 , which is about $15 \%(16.4 \% \pm 3.93 \%$,
TABLE 2. Number of germ cells per Sertoli cell*

Cell type

Average $( \pm \mathrm{SEM})$

Preleptotene, leptotene, or

zygotene primary

$2.34 \pm 0.82$

spermatocytes

Pachytene or diplotene

primary spermatocytes

$2.37 \pm 0.064$

Secondary spermatocytes

$4.04 \pm 0.233$

Spermatids (steps 1-10)

$7.89 \pm 0.270$

*Ratios derived from cell numbers per unit length $(\mathrm{cm})$ of the seminiferous tubule.

SEM) lower than the value, 4.0 , that would be expected in the absence of any cell death.

Germ-cell-to-Sertoli-cell numerical ratios have been derived by dividing the average number of a category of germ cells per unit length of the seminiferous tubule by the number of Sertoli cells contained in that length. As is shown in Table 2, the average number of younger generation (preleptotene, leptotene, zygotene) primary spermatocytes per Sertoli cell is $2.34-0.082$; the number of older gener- 


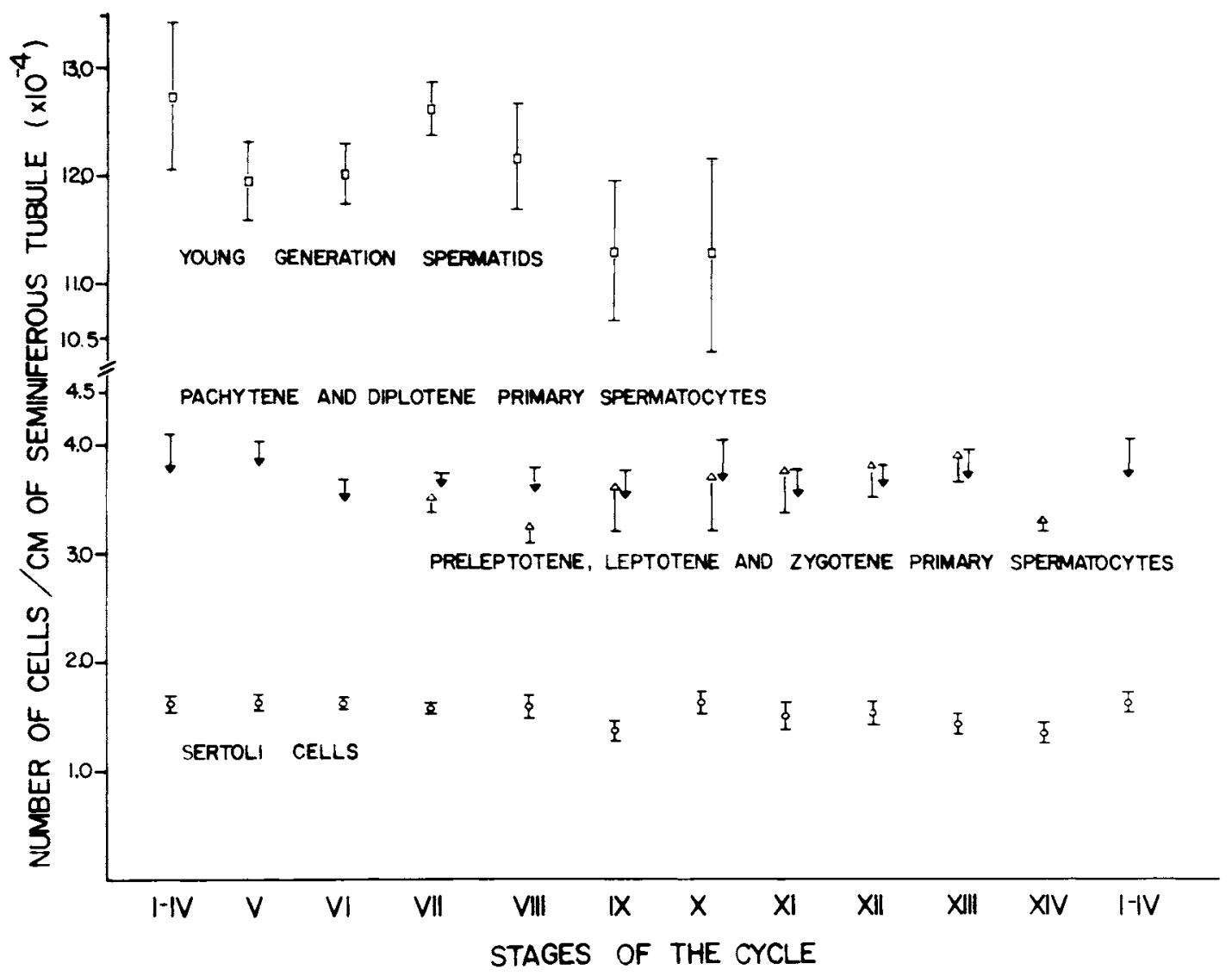

Fig. 4. Number of various categories of cells per unit length of the seminiferous tubule at successive stages of the cycle. There is no significant difference in cell number for a given category between any two stages. ation (pachytene, diplotene) primary spermatocytes per Sertoli cell is $2.37 \pm 0.064$ (SEM); and there are $4.04 \pm 0.233$ secondary spermatocytes and $7.89 \bullet 0.270$ spermatids for each Sertoli cell.

At stage $\mathrm{V}$ of the cycle, the step-17 spermatids are located in clusters in the Sertoli-cell cytoplasmic trunks. The results of our counts on serial sections (Fig. 5) show an average of $8.35 \pm 0.128$ (SEM, $\mathrm{n}=100$ ) spermatids per cluster, but the number ranged from 6 to 11 . In no case did two clusters converge on the same Sertoli nucleus.

Sertoli-cell and germ-cell numbers per testis and per gram of testis can be found in Table 3 . A gram of testis contains 15.7 million Sertoli cells, 20.5 million younger generation primary spermatocytes, 35.8 million older generation (pachytene, diplotene) primary spermatocytes,
2.5 million secondary spermatocytes, and 93.4 million step $1-10$ spermatids.

The average length of seminiferous tubule in a gram of rat testis is $12.39 \pm 0.56 \mathrm{~m}$, and the surface area of these tubules per gram testis is $119.7 \pm 2.57 \mathrm{~cm}^{2}$. The corresponding values per average testis in the present study are $17.4 \mathrm{~m}$ of seminiferous tubule and $168.5 \mathrm{~cm}^{2}$ of surface area.

In assessing the daily rate of sperm production, based on counts of step 1-10 spermatids, it is important to know whether there is significant loss of spermatids after step 10 . From the number of step-17 spermatids we found clustered in Sertoli cell cytoplasm, as well as the fact that we did not observe evidence for a reported loss at about stages 9-10 (see Discussion), we felt justified in concluding that no significant loss of spermatids occurs during the 
19 steps of spermiogenesis. The time necessary to process the total number of step 1-10 spermatids in a testis (or gram of testis) would thus be the time period from stages I through $\mathrm{X}$ of the cycle. The complete cycle in Sprague-Dawley rats has a duration of 12.9 days (Clermont and Harvey, 1965). The time necessary for the cycle to proceed from stage I to stage $\mathrm{X}$ is $75.58 \% \pm 1.45 \%$ of the total cycle (Clermont and Harvey, 1965; Perey et al., 1961; Leblond and Clermont, 1952a; and measurements car-

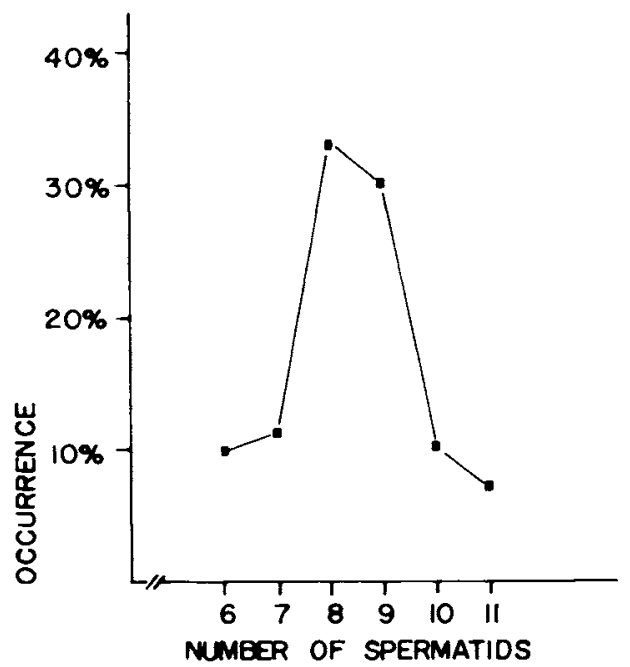

Fig. 5. Number of step-17 spermatids per cluster at stage $V$ of the cycle. Each cluster is embedded in a trunk of Sertoli cell cytoplasm. The range of values, from 6 to 11 , shows that the mechanism by which the spermatids are segregated to the Sertoli cell trunks allows a certain flexibility in the number of spermatids included in the clusters. ried out in the present study), which would correspond to a duration of $9.75 \pm 0.187$ days. The average daily production of sperm per testis is therefore $13.42 \times 10^{6} \pm 1.022 \times 10^{6}$ (SEM), and the rate per gram (or $\mathrm{cm}^{3}$ ) of testis is $9.61 \times 10^{6} \pm 0.615 \times 10^{6}$.

\section{DISCUSSION}

In this study we have assessed various quantitative aspects of rat seminiferous tubules, using current morphometric methods, with care to provide adequate sampling and statistical analysis.

The effect of volume change during tissue preparation has been corrected for in the present study to give values corresponding to the fresh organ. In this study, the net shrinkage of testicular tissue from the fresh condition to sections was found to be $21 \%$ in one dimension, thus making the volume of the tissue in sections only $52.2 \%$ of its volume in the fresh condition. Such corrections have not been utilized commonly in the literature on testicular quantitation; an exception is de Jong and Sharpe (1977a,b).

Many of the previous quantitative studies on the rat spermatogenic process have been concerned with where cell death occurs during spermatogenesis. Those studies have utilized various sampling, histological, and analytical techniques. Roosen-Runge and his co-workers (1951; 1955a,b; Roosen-Runge and Giesel, 1950) did early work on the quantitative changes in the seminiferous tubule at different stages of the cycle of the seminiferous epithelium. RoosenRunge (1955a; 1962) counted germ-cell-to-Sertoli-cell ratios on whole-mount preparations and claimed a $22 \%$ cell loss from preleptotene primary spermatocytes to maturation-phase spermatids. From the percentage of "degener-

TABLE 3. Sertoli and germ cell numbers per testis and per gram* of testis $( \pm S E M) \dagger$

\begin{tabular}{lrr}
\hline & Per testis & Per gram of testis \\
\hline Sertoli cells & $21.9 \times 10^{6} \pm 1.70 \times 10^{6}$ & $15.7 \times 10^{6} \pm 0.99 \times 10^{6}$ \\
$\begin{array}{l}\text { Preleptotene, leptotene, and zygotene } \\
\text { primary spermatocytes }\end{array}$ & $28.8 \times 10^{6} \pm 3.59 \times 10^{6}$ & $20.5 \times 10^{6} \pm 2.11 \times 10^{6}$ \\
$\begin{array}{l}\text { Pachytene and diplotene } \\
\text { primary spermatocytes }\end{array}$ & $50.2 \times 10^{6} \pm 5.25 \times 10^{6}$ & $35.8 \times 10^{6} \pm 3.06 \times 10^{6}$ \\
$\begin{array}{l}\text { Secondary spermatocytes } \\
\text { Spermatids (steps 1-10) }\end{array}$ & $3.51 \times 10^{6} \pm 0.682 \times 10^{6}$ & $2.47 \times 10^{6} \pm 0.419 \times 10^{6}$ \\
\hline
\end{tabular}

*Since the specific gravity of fresh testis in the rat is nearly unity $(1.040 \pm 0.004 \pm$ SEM, Mori and Christensen, 1980$)$, values per gram are interchangeable with values per $\mathrm{cm}^{3}$.

tDerived from the estimates of four animals and corrected for the volume change in tissue preparation. 
ating figures," there appeared to be an approximate $10 \%$ decline in leptotene and zygotene primary spermatocytes, a $2 \%$ loss at the first meiotic division, no loss in the second meiotic division, and a $10 \%$ reduction in the number of cells during spermiogenesis in step 9-10 spermatids. In the present study, we did not observe a significant change in the number of leptotene or zygotene primary spermatocytes over pertinent stages of the cycle (Fig. 4). Neither did we discern any degenerating step 9-10 spermatids.

Clermont (1962) compared the cell numbers of various generations of germ cells per crosssection of rat seminiferous tubules (with correlated autoradiography) and concluded that there was a $12 \%$ cell loss during the first meiotic division and a $15 \%$ loss in the second. Our counts show a $15 \%$ loss in the first division but do not disclose any further loss in the second meiotic division. The autoradiographic observations by Clermont (1962) suggested that most of the degeneration figures described by Roosen-Runge (1955a) as young (leptotene, zygotene) primary spermatocytes or step 9-10 spermatids were probably degenerating type A spermatogonia. Russell and Clermont (1977) reported cell death at other phases of spermatogenesis, but those losses were infrequent and thus may fail to cause a discernible change in the cell population during sperm development.

The $15 \%$ incidence of cell death among cells undergoing the first meiotic division may be caused by chromosomal problems resulting from the complex chromosomal interactions (Moens, 1973) that take place during the long prophase preceding that division. Included in the events of that prophase are synapsis, possible crossing over, and disjunction. The first meiotic division could thus constitute a decisive moment when any difficulties encountered during those chromosomal interactions may manifest themselves as an inability to complete the division.

There is an intriguing similarity in the number of Sertoli cells reported here, about 16 million per gram of testis, and the 21 million Leydig cells per gram of testis reported previously from our laboratory (Mori and Christensen, 1980). The significance, if any, of this similarity is not clear.

De Jong and Sharpe (1977a,b) carried out cell counts per seminiferous-tubule cross section in testes of Hooded Liverpool rats as part of a study on the effect of neonatal irradiation on rat testes, leading to the conclusion that Sertoli cells are the most likely source of inhibin. They counted nuclei of type A spermatogonia and pachytene primary spermatocytes, as well as nucleoli of Sertoli cells, and converted the average values to cells per animal by means of Abercrombie's (1946) formula (with nuclear diameters calculated from the literature), a factor for conversion to cells per testis from the literature, and a factor compensating for shrinkage of the testis during preparation for light microscopy. In their 81-day-old adult controls, they reported an average of 60.4 million Sertoli cells and 114.4 million pachytene primary spermatocytes per animal. The corresponding values in our study would be 43.8 million Sertoli cells and 100.4 million pachytene primary spermatocytes (the average age of our four Sprague-Dawley rats was 68 days).

Sertoli cell counts by Bustos-Obregon (1970) in whole-mounts of fixed tubules at stages II-IV, V, and VII of the cycle yielded average values of about 18.2 Sertoli cells per $10,000 \mu \mathrm{m}^{2}$ of tubule surface. The corresponding value in the present study is 13.1 Sertoli cells per $10,000 \mu \mathrm{m}^{2}$ of tubule surface, obtained by dividing the number of Sertoli cells per gram testis by the tubule surface area per gram testis (see Results), and then adjusting the dimensions. The lower value obtained here may reflect the fact that our data are corrected to correspond to values in the fresh testis; conventional histological fixation by immersion would tend to shrink the tubules somewhat, which could give rise to a larger number of nuclei per unit area of tubule surface.

Each Sertoli cell is in contact with a considerable number of germ cells, most of which are shared between adjacent Sertoli cells. However, the net "workload" for the individual Sertoli cell is indicated by the number of a particular type of germ cell per Sertoli cell. This value is 2.34 for young (preleptotene, leptotene, zygotene) primary spermatocytes, 2.37 for older (pachytene, diplotene) primary spermatocytes, 4.04 for secondary spermatocytes, and 7.89 for round spermatids (steps 1-10). Our values for young and old primary spermatocytes, averaged for all pertinent stages, are similar to the 2.47 count obtained for primary spermatocytes at one stage by Roosen-Runge (1955a) in whole-mount preparations.

Other workers have studied the number of older spermatids constituting individual clusters in the Sertoli-cell trunks. Rolshoven (1941), in counts on serial sections, obtained a bimodal distribution, with a tall, narrow peak at eight spermatids per Sertoli cell and a second, smaller peak at 12 spermatids per Sertoli cell. Roosen-Runge (1955a), on the other hand, using whole mounts, found a peak at nine sper- 
matids (average 8.85) per Sertoli cell, but encountered no second peak. We also failed to find any second peak (Fig. 5). Our average of 8.35 step-17 spermatids per Sertoli cell is somewhat lower than that of Roosen-Runge (1955a), although our range (6-11 spermatids) is very similar to his (6-12 spermatids). A comparison of our 8.35 average of older spermatids per Sertoli cell with our mean value of 7.89 for step 1-10 spermatids per Sertoli cell (see Results), suggests that a small fraction of Sertoli cells may not be associated with maturing spermatid clusters during stage $V$ of the cycle. The rather wide range in the number of spermatids in the clusters, from 6 to 11 , betrays a certain latitude in the process by which younger spermatids become clustered into the Sertoli cytoplasmic trunks after stage VIII of the cycle.

Results of the present study show that the numbers of Sertoli cells and major germ-cell types per unit length of seminiferous tubule remain essentially constant throughout all stages of the cycle of the seminiferous epithelium. This is consistent with the finding of Bustos-Obregon (1970), from Sertoli-cell counts in whole mounts of seminiferous tubules at stages II-IV, V, and VII, and extends his results to all stages of the cycle. In the present study, this is demonstrated by studying the number of cells per unit length of seminiferous tubule. It could not be established accurately by measuring only numerical densities of the cells in sections since, as is shown in this study, the diameter of the seminiferous tubule, which is the reference volume for the numerical density, changes significantly at some stages of the cycle. Since the numerical density, by definition, is a ratio (e.g., cell number per $\mathrm{cm}^{3}$ of tissue), a change in the reference volume which constitutes the denominator will change the value of the ratio, independently of changes in cell number. The approach used in this paper was devised to avoid this difficulty.

Our estimate of daily sperm production can be compared with two previous estimates. Amann (1970) predicted that daily sperm production in rats would be only one-half of the value in rabbits, which he had estimated at 26 million sperm per day/per gram of testis. That estimate would be close to the findings in the present study, in which the daily sperm production per gram of rat testis has been found to be close to 10 million. 'The daily sperm production per gram of rat testis reported by Johnson et al. (1980), 21.1 million per gram testis or twice our value, is rather close to the estimate that would have been obtained in the present study if the necessary correction for volume change had not been carried out. Those authors measured the diameter of spermatid nuclei before and after dehydration and embedding, and concluded that the shrinkage of Epon-Araldite embedded tissue was negligible, which differs from our findings.

Many of the quantitative changes in the seminiferous tubule shown in this study presumably relate to functional alterations taking place during the cycle of the seminiferous epithelium in the tubule. The evolutions of our knowledge on the hormonal control of spermatogenesis has been reviewed by several authors (Courot et al., 1970; Steinberger, 1971; Steinberger and Steinberger, 1973, 1975; Hansson et al., 1976). There appear to be striking regional differences in hormone binding and other functions along the seminiferous tubule. Parvinen et al. (1980) have shown that FSH binding is highest in seminiferous tubules in stages XIII-I, the most elevated cAMP response is at stages II-VI, while the maxiumum storage of androgen-binding protein $(\mathrm{ABP})$ is at stages VII-VIII. Parvinen and Vanha-Perttula (1972) showed a regional difference in lytic enzyme contents along the length of the seminiferous tubule, with stages VI-VIII containing the highest activities. In the process of spermiation, significant decreases in the lumen and diameter of the seminiferous tubule (present findings), decreased amounts of demonstrable lipid droplets (Niemi and Kormano, 1965), decreased acid-phosphatase activities (Parvinen and Vanha-Perttula, 1972), and decreased ABP production (Parvinen et al., 1980) have been shown. Studies on various aspects of spermatogenesis require a knowledge of the interactions between germ cells and Sertoli cells, and also of how these change during successive stages of the cycle. It is hoped that the present investigation may help elucidate quantitative aspects of these relationships.

\section{LITERATURE CITED}

Abercrombie, M. 1946 Estimation of nuclear population from microtome sections. Anat. Rec., 94:239-247.

Amann, R.P. 1970 Sperm production rates. In: The Testis. Vol.1, Development, Anatomy and Physiology. A.D. Johnson, W.R. Gomes, and N.L. Van Demark, eds. Academic Press, New York, pp. 433-482.

Bolender, R.P. 1978 Correlation of morphometry and stereology with biochemical analysis of cell fractions. Int. Rev. Cytol., 55:247-289.

Bustos-Obregon, E. 1970 On Sertoli cell number and distribution in rat testis. Arch. Biol. (Liege), 81:99-108.

Christensen, A.K. 1965 The fine structure of testicular interstitial cells in guinea pigs. J. Cell Biol., 26:911-935. 
Christensen, A.K., and K.C. Peacock 1980 Increase in Leydig cell number in testes of adult rats treated chronically with an excess of human chorionic gonadotropin. Biol. Reprod., 22:383-391.

Clermont, Y. 1962 Quantitative analysis of spermatogenesis of the rat: A revised model for the renewal of spermatogonia. Am. J. Anat., 111:111-130.

Clermont, Y., and S.C. Harvey 1965 Duration of the cycle of the seminiferous epithelium of normal, hypophysectomized and hypophysectomized-hormone treated albino rats. Endocrinology, 76:80-89.

Clermont, Y., and $\mathrm{L}$. Hermo 1975 Spermatogonial stem cells in the albino rat. Am. J. Anat., 142:159-176.

Clermont, Y., and C. Huckins 1961 Microscopic anatomy of the sex cords and seminiferous tubules in growing and adult male albino rats. Am. J. Anat., 108:79-98.

Clermont, Y., and C.P. Leblond 1953 Renewal of spermatogonia in the rat. Am. J. Anat., 93:475-502.

Clermont, Y., and H. Morgentaler 1955 Quantitative study of spermatogenesis in the hypophysectomized rat. Endocrinology, 57:369-382.

Clermont, Y., and B. Perey 1957 Quantitative study of the cell population of the seminiferous tubules in immature rats. Am. J. Anat., 100:241-268.

Courot, M., M.-T. Hochereau-de Reviers, and R. Ortavant 1970 Spermatogenesis. In: The Testis. Vol. 1, Development, Anatomy and Physiology. A.D. Johnson, W.R. Gomes, and M.L. Van Demark, eds. Academic Press, New York, pp 339-432.

de Jong, F.H., and R.M. Sharpe 1977a The onset and establishment of spermatogenesis in rats in relation to gonadotrophin and testosterone levels. J. Endocrinology, 75:197-207.

de Jong, F.H., and R.M. Sharpe 1977b Gonadotrophins, testosterone and spermatogenesis in neonatally irradiated male rats: Evidence for a role of the Sertoli cell in follicle-stimulating hormone feedback. J. Endocrinology, 75:209-219

Elias, H., and D.M. Hyde 1980 An elementary introduction to stereology (quantitative microscopy). Am. J. Anat., 159:411-446.

Floderus, S. 1944 Untersuchungen uber den Bau der menschlichen Hypophyse mit besonderer Berucksichtigung der quantitativen mikromorphologischen Verhaltnisse. Acta path. microbiol. Scand. Suppl., 53:1-276.

Fox,D.J., and K.E. Guire 1976 Documentation for MIDAS, 3rd ed. Statistical Research Laboratory, Univ. Michigan, Ann Arbor.

Hansson, V., R. Calandra, K. Purvis, M. Ritzen, and F.S. French 1976 Hormonal regulation of spermatogenesis. Vit. Horm., 34:187-214.

Johnson, L., C.S. Petty, and W.B. Neaves 1980 A comparative study of daily sperm production and testicular composition in humans and rats. Biol. Reprod., 22: 1233-1243.

Leblond, C.P., and Y. Clermont 1952a Definition of the stages of the cycle of the seminiferous epithelium in the rat. Ann. N.Y. Acad. Sci., 55:548-573.

Leblond, C.P., and Y. Clermont 1952b Spermiogenesis of rat, mouse, hamster and guinea pig as revealed by the "periodic acid-fuchsin sulfurous acid" technique. Am. J. Anat., 90:167-216.

Moens, P.B. 1973 Mechanisms of chromosome synapsis at meiotic prophase. Int. Rev. Cytol., 35:117-134.

Mori, H., and A.K. Christensen 1980 Morphometric analysis of Leydig cells in the normal rat testis. J. Cell Biol., 84:340-354.

Niemi, M., and M. Kormono 1965 Cyclical changes in and significance of lipids and acid phosphatase activity in the seminiferous tubules of the rat testis. Anat. Rec., 151: 159-170.

Parvinen, M., and T. Vanha-Perttula 1972 Identification and enzyme quantitation of the stages of the seminiferous epithelial wave in the rat. Anat. Rec., 174:435-450.

Parvinen, M., R. Marana, D.M. Robertson, V. Hansson, and and E.M. Rizen 1980 Functional cycle of rat Sertoli cells: Differential binding and action of follicle stimulating hormone at various stages of the spermatogenic cycle. In: Testicular Development, Structure, and Function. A. Steinberger, and E. Steinberger, eds. Raven Press, New York, pp. 425-432.

Perey, B., Y. Clermont, and C.P. Leblond 1961 The wave of the seminiferous epithelium in the rat. Am. J. Anat., 108:47-78.

Rolshoven, E. 1941 Zur Frage des "Alterns" der generativen Elemente in den Hodenkanalchen. Anat. Anz., 91: $1-8$.

Roosen-Runge, E.C. 1951 Quantitative studies on spermatogenesis in the albino rat. II. The duration of spermatogenesis and some effects of colchicine. Am. J. Anat., 88:163-176.

Roosen-Runge, E.C. 1955a Untersuchungen uber die Degeneration Samenbildender Zellen in der normalen Spermatogenese der Ratte. Zeit. f. Zellforsh. Mikros. Anat., 41:221-235.

Roosen-Runge, E.C. $1955 \mathrm{~b}$ Quantitative studies on spermatogenesis in the albino rat. III. Volume changes in the cells of the seminiferous tubules. Anat. Rec., 123:385-398.

Roosen-Runge, E.C. 1962 The process of spermatogenesis in mammals. Biol. Rev., 37:343-377.

Roosen-Runge, E.C., and L.O. Giesel, Jr., 1950 Quantitative studies on spermatogenesis in the albino rat. Am. J. Anat., 87:1-30.

Russell, L.D., and Y. Clermont 1977 Degeneration of germ cells in normal, hypophysectomized and hormone treated hypophysectomized rats. Anat. Rec., 187: 347-366.

Snedecor, G.W., and W.G. Cochran 1980 Statistical Methods, 7 th ed. Iowa State Univ. Press, Ames, Iowa.

Steinberger, E. 1971 Hormonal control of mammalian spermatogenesis. Physiol. Rev., 51:1-22.

Steinberger, A., and E. Steinberger 1973 Hormonal control of mammalian spermatogenesis. In: The Regulation of Mammalian Reproduction. C.J. Segal, R. Crozier, P.A. Corfman, and P.G. Condliffe, eds. Charles C. Thomas Publisher, Springfield, IL, pp. 139-150.

Steinberger, E. and A. Steinberger 1975 Spermatogenic function of the testis. In: Handbook of Physiology, Sec. 7, Vol. 5. D.W. Hamilton, and R.O. Greep, eds. Am. Physiol. Soc., Washington, D.C., pp. 1-19.

Weibel, E.R., and R.P. Bolender 1973 Stereological techniques for electron microscopic morphometry. In: Principles and Techniques for Electron Microscopy. Vol 3. M.A. Hayat, ed. Van Nostrand-Reinhold, New York, pp. 237-296. 